\title{
Impact of KSE-100 Index on Oil Prices and Gold Prices in Pakistan
}

\begin{abstract}
Abdul Basit
Abstract: Investments in stocks, gold and oil contracts are always thought to be the best source of investment in developing markets. Investors keep on swapping their investment in different investments options to gain the maximum return. In Pakistan stock market, gold and oil investments are ranked among the most desirable area of investments. In this paper the researcher tired to study that how KSE-10O Index affects the oil and gold prices in Pakistani market. This paper will help the investor to investigate the relationship in the said investment options in Pakistan. For this purpose the researcher on the basis of available secondary data collected the KSE100 Index, oil prices and gold prices for the time period 2005 to 2011. The researcher took oil price and gold prices as dependent variables where as KSE-100 Index is taken as independent variable. The researcher applied the simple regression models separately for both dependent variables and concluded that there is no obvious relationship in these variables.

Keywords: Gold Prices, oil Prices, KSE-100 Index
\end{abstract}

\section{Introduction}

Financial investment refers to putting aside a fixed amount of money and expecting some kind of gain out of it within a stipulated time frame. Mutual Funds, Fixed Deposits, Bonds, Stock Equities, Real Estate, Gold /Silver and Precious stones are different types of Financial Investment. Investors of Pakistan are also diversifying their investment into gold, because such investments typically have had an inverse relationship with stock market movements. Investment in the gold is considered as the safest investment today. There are many reasons for that but because of old traditions and customs gold is very important in this part of the world. Gold is necessary item in any marriage function especially in South Asia. Now Governments all around the world trying to fill their treasuries with gold and as a result it greatly pushed the price of this precious commodity. Oil price shocks have raised serious concerns among the policy makers around the world, because of its adverse impacts for the net oil importing economies. Oil was initially traded for its fundamental purposes, but over time gained a permanent place in the investment portfolio. Oil and its derivates are specific with high liquidity, volatility and relatively high profit opportunities for investors. Price formation is an important factor influencing the oil market. Determining the price of this commodity is derived from the market mechanism. According to Balaz (2002), the oil market is differentiated from other commodity market by certain specifics. Karachi Stock Exchange is the biggest and most liquid exchange in Pakistan, it has been declared as the "Best Performing Stock Market of the World for the year 2002" by "Business Week".

\section{Objective of the Study:}

The objective of this study is to check how stock Index is affected the gold prices and oil prices in Pakistani stock market. The study was conducted by taking stock index as independent variable and oil price and gold prices as dependent variables.

\section{Review of Literature}

In literature the researchers have studied these variables in different dimensions and were able to derive different results on it. Literature was observed with mix results like in some parts it is found positive, where in some parts of worlds it's found negative and literature also proves that in some economies these variables have no relationship.

Positive relationship was observed in gold price and stock prices in US by Levin and Wright (2006), the study reveals the positive relationship between changes in the gold price and changes in the US dollar tradeweighted rate and the gold lease rate. Mu-Lan Wang, Ching-Ping Wang and Tzu-Ying Huang (2010) also investigate the impact of fluctuations in gold price, crude oil prices, and exchange rates of the U.S. dollar vs. various currencies on the stock price indices of the United States, Germany, Japan, Taiwan and china. The result shows that there exists co-integration and long term stable relationship among these variables. But contrary to it there is no co-integration and long term stable relationship among these variables in USA.

Researchers also concluded the negative relationship between these variables, Moore (1990) investigated the negative correlation between gold price and the stock/bond markets. It means that when gold prices are rising, the stock/bond markets are declining. The result derived on the basis of empirical result from 1970 to 1988. 
Similarly Neda (2011) investigated during the period of 2006 to 2010 the negative relationship between stock exchange index and gold price in Iran and Armenia. Tests also show that the time series of study are stationery and there exists long run relationship between them. on the other hand Ratanapakorn and Sharma (2007) investigate the long-term and short-term relationship among the U.S. stock price index and macroeconomic variables and were able to conclude that the stock price index and long-term interest rate are negatively correlated, but money supply, industrial production index, inflation rate, exchange rate, and short-term interest rate are positively correlated. Turkish market also observed the conduct of this and Ahmet (2010) analyzed that the interest rate, industrial production index, oil price, foreign exchange rate have a negative effect on ISE-100 index returns but money supply positively affect the ISE-100 index returns. But the inflation rate and price of gold do not affect the ISE-100 index returns. Hina \& Naveed (2010) also investigated the negative relationship between the gold rates and KSE-100 Index for data collected on monthly basis for the period of 2006 to 2010, Graham smith (2002) investigate the relationship between the gold price and stock price indices for Europe and Japan. He conclude that the short run correlation is small and negative in European markets and Japan, there is no long run equilibrium between them and no co integration occur. Data was collected from the period 1991 to 2001.

Literature also examines that their no obvious relationship between different combinations of these variables. Graham smith (2001) analyze empirical evidence on the relationship between the gold price and stock price indices for the United States. He uses data from January 1991 to October 2001. According to the study there is no obvious relationship in the long run, but in the short run, the gold price is affected by the stock price. Chakravarty (2006) also studied the relationship between stock price and macro economic variables in India. $\mathrm{He}$ uses monthly time series data from the period 1991-2005. The study indicates that is no causal relation between stock price and exchange rate. Similarly there is no causal linkage between gold price and oil price.

P K Mishra, J R Das and S K Mishra (2010) investigate the relationship between gold prices and stock market returns in India. The result shows that time series of study is stationary. There exists long run equilibrium relationship. Then Granger's causality test suggests that causality running between variables. Data was collected from the period of January 1991 to December 2009. Mahendru and Sharma (2010) investigated that exchange rate and gold prices highly affect the stock prices. Data was collected from the period of 2008 to 2009. They use different macroeconomic variables in this study. Tursoy, Gunsel and Rjoub (2008) they tested 13 macroeconomic variables (money supply, industrial production, crude oil price, consumer price index, import export, gold price, interest rate, exchange rate, gross domestic products, foreign reserve, unemployment rate and market pressure index) against 11 industry portfolios of Istanbul stock exchange to observe the effect of those variables on stocks returns. Using ordinary least technique, they observed that there are some differences among industry sector portfolios.

On the basis on above literature researcher studied the impact of the KSE-100 index on gold price and oil prices in Pakistan. The research design is unique because in Pakistan on KSE-100 Index though these variables have been studied in different relationship and research designs but the impact of KSE-100 Index on gold prices and oil prices, by taking KSE-100 Index as independent and oil prices and gold prices as dependent variables.

\section{Data collection}

\section{Methodology}

This paper examines the impact of gold prices and oil prices on stock returns of KSE-100 Index in Pakistan for the period 1 Jan, 2005 to Dec 31, 2011. The study has analyzed the monthly data on domestic gold price and oil prices on stock market returns in Pakistan. Data collected in this research was through secondary method. The value of KSE-100 index has been taken from the wed site Yahoo Finance and values of gold prices and gold prices have been taken from the web site Forex.

Model : The regression models is as under:

$\boldsymbol{G P} \boldsymbol{P}_{i, t}=\boldsymbol{\alpha}_{i, t}+\boldsymbol{\beta}_{1} S \boldsymbol{I}_{i, t}+\boldsymbol{\mu}_{i, t}$

$O P_{i, t}=\alpha_{i, t}+\beta_{2} S I_{i, t}+\mu_{i, t}$

Where:

$S I=K S E-100$ Index,$G P=$ Gold Price, $O P=$ Oil Price

\section{Results and Analysis}

The researcher conducted the simple regression analysis to study the impact of the KSE-100 Index on the gold prices in Pakistan. for this purpose following linear equation has been developed:

$\boldsymbol{G P}_{i, t}=\boldsymbol{\alpha}_{i, t}+\boldsymbol{\beta}_{1} \boldsymbol{S} \boldsymbol{I}_{i, t}+\boldsymbol{\mu}_{i, t}$

Researchers used the SPSS 16 to run the test and concluded the following results: 
Model Summary

\begin{tabular}{|c|c|c|c|c|c|c|c|c|c|c|}
\hline \multirow[b]{2}{*}{ Mode } & \multirow[b]{2}{*}{$\mathrm{R}$} & \multirow[b]{2}{*}{ RSguare } & \multirow[b]{2}{*}{$\begin{array}{l}\text { Adjusted R } \\
\text { Square }\end{array}$} & \multirow[b]{2}{*}{$\begin{array}{l}\text { Std Error of of } \\
\text { the Estimate }\end{array}$} & \multicolumn{5}{|c|}{ Change Statistics } & \multirow[b]{2}{*}{$\begin{array}{l}\text { Durbin- } \\
\text { Whatson }\end{array}$} \\
\hline & & & & & $\begin{array}{l}\text { R Square } \\
\text { change }\end{array}$ & F Change & dfil & $d t 2$ & Sig. F change & \\
\hline 1 & $.158^{\circ}$ & .025 & .013 & 2261.27985 & .025 & 2.102 & 1 & 82 & .151 & .138 \\
\hline
\end{tabular}

a. Predictors: (Constant), S1

b. Dependent Variable: $G P$

Coefficients ${ }^{2}$

\begin{tabular}{|c|c|c|c|c|c|c|c|c|}
\hline \multirow[b]{2}{*}{ Madel } & & \multicolumn{2}{|c|}{ Unstandardized Coefficients } & \multirow{2}{*}{$\begin{array}{c}\begin{array}{c}\text { Standardized } \\
\text { Coefficients }\end{array} \\
\text { Beta } \\
\end{array}$} & \multirow[b]{2}{*}{$t$} & \multirow[b]{2}{*}{ Sig. } & \multicolumn{2}{|c|}{$95 \%$ Confidence Interval for B } \\
\hline & & $B$ & Std. Error & & & & Lower Bound & Upper Bound \\
\hline & (Constant) & 9705.516 & 521.019 & & 18.628 & .000 & 8669.044 & 10741.989 \\
\hline & 8 & .030 & .020 & .158 & 1.450 & .151 & -011 & .070 \\
\hline
\end{tabular}

a. Dependent Variable: GP

The results show that there was a positive relationship observed in Gold Prices and KSE-100 Index. but the relationship was not observed as a strong relationship between the variables. the relationship is observed as slightly positive which depicts that around $16 \%$ change in gold prices are due to the change in the KSE-100 Index but the rest of $84 \%$ is due to other factors in the economy. Researcher concludes that the KSE-100 Index donot have significant impact on gold prices. Like Graham smith (2001) and Chakravarty (2006), researchers also conclude that there was not a obvious and significant relationship between Gold Prices and KSE-100 Index in Pakistani economy.

The researcher conducted the simple regression analysis to study the impact of the KSE-100 Index on the oil prices in Pakistan. For this purpose following linear equation has been developed:

$\boldsymbol{O P} \boldsymbol{P}_{i, t}=\boldsymbol{\alpha}_{i, t}+\boldsymbol{\beta}_{2} S \boldsymbol{I}_{i, t}+\boldsymbol{\mu}_{i, t}$

Researchers used the SPSS 16 to run the test and concluded the following results:

Model Summary

\begin{tabular}{|c|c|c|c|c|c|c|c|c|c|c|}
\hline \multirow[b]{2}{*}{$\begin{array}{l}\text { Mode } \\
\perp\end{array}$} & \multirow[b]{2}{*}{$\mathrm{R}$} & \multirow[b]{2}{*}{ R Square } & \multirow[b]{2}{*}{$\begin{array}{c}\text { Adjusted R } \\
\text { Square } \\
\end{array}$} & \multirow[b]{2}{*}{$\begin{array}{r}\text { Std. Error of } \\
\text { the Estimate }\end{array}$} & \multicolumn{5}{|c|}{ Change Statistics } & \multirow[b]{2}{*}{$\begin{array}{l}\text { Durbin- } \\
\text { Watson } \\
\end{array}$} \\
\hline & & & & & $\begin{array}{l}\text { R Square } \\
\text { Change }\end{array}$ & Fchange & df1 & $d f 2$ & Sig. F Change & \\
\hline 1 & $.174^{2}$ & .030 & .018 & 25.457 & .030 & 2.560 & 1 & 82 & .113 & .771 \\
\hline
\end{tabular}

Coefficients

\begin{tabular}{|c|c|c|c|c|c|c|c|c|}
\hline \multirow[b]{2}{*}{ Model } & & \multicolumn{2}{|c|}{ Unstandardized Coefficients } & \multirow{2}{*}{$\begin{array}{c}\begin{array}{c}\text { Standardized } \\
\text { Coefficients }\end{array} \\
\text { Beta } \\
\end{array}$} & \multirow[b]{2}{*}{$t$} & \multirow[b]{2}{*}{ Siq. } & \multicolumn{2}{|c|}{$95 \%$ Confidence Interval for $\mathrm{B}$} \\
\hline & & B & Std. Error & & & & Lower Bound & Upper Bound \\
\hline 1 & (Constant) & 65.659 & 5.866 & & 11.194 & .000 & 53.990 & 77.327 \\
\hline & 81 & .000 & .000 & -.174 & -1.600 & .113 & .000 & .000 \\
\hline
\end{tabular}

a. Dependent Variable: $O P$

The results show that there was a positive relationship observed in oil Prices and KSE-100 Index. But the relationship was not observed as a strong relationship between the variables. The relationship is observed as slightly positive which depicts that around 17\% change in gold prices are due to the change in the KSE-100 Index but the rest of $83 \%$ is due to other factors in the economy. Researcher concludes that the KSE-100 Index do not have significant impact on oil prices. Like Chakravarty (2006) researchers also conclude that there was not an obvious and significant relationship between oil Prices and KSE-100 Index in Pakistani economy.

\section{Conclusion}

Investments in stocks, gold and oil contracts are always thought to be the best source of investment in developing markets. Investors keep on swapping their investment in different investments options to gain the maximum return. Stock market is considered to be the most active investment market in Pakistan In this paper 
the researcher studied that how KSE-100 Index affects the oil and gold prices in Pakistani market. The researcher on the basis of available secondary data collected the KSE-100 Index, oil prices and gold prices for the time period 2005 to 2011 and took oil price and gold prices as dependent variables where as KSE-100 Index is taken as independent variable. The researcher then run the simple regression models on data and concluded that there is no obvious relationship in these variables. The results shows that only $16 \%$ variations in the gold prices is due to the change in the KSE-100 Index where as the 17\% change is observed in the oil prices is due to change in the KSE-100 Index. The researcher conclude that as the $84 \%$ change in gold prices is due to other variables and $83 \%$ change is oil prices is due to other variables, KSE-100 Index can not be declared as a major source of change. There could be the set of other macro variables that also affect the oil and gold prices in Pakistan.

\section{References}

[1] Ahmet, The Effect of Macroeconoics Variables on Stock Return: Evidence from Turkey, European Journal of Social Science Volume 14, Number 3 (2010).

[2] Basher and Sadorsky, Oil price risk and emerging stock markets, Globel Finance Journal 17 (2006) 224-251

[3] Chung S. Kwon and Tai S. Shin (1999), Cointegration and Causality between Macroeconomic Variables and Stock Markets Returns, Globel Finance Journal, 10(1), 71-81.

[4] Claire, Ginette, Rajneesh and Ahmet, The Dynamics of Gold Prices, Gold Mining Stock prices and Stock Market Prices Comovements, Research in Applied Economics ,Issue 2009, Vol. 1, No. 1: E12

[5] Graham Smith (2001), The Price of Gold and Stock Price Indices for the United States, Adrienne Roberts FT Personal Finance, October 27, 2011, p 14.

[6] Grorge Handroyiannis and Evangelia Papapetrou (2001), Macroeconomic Influences on the Stock Market, Journal of Economics and Finance, 25(1), 33-49.

[7] Hamed Sadri and Ehsan TayebiSani (2012), the Impact of Crude Oil, Gold Price \& Their Volatilities on Stock Markets: Evidence from Selected Member of OPEC, Journal of Basic and Applied Scientific Research, 2(10)10472-10479, 2012.

[8] Kuan-Min Wang and Yuan-Ming Lee, Could Gold Serve as Exchange Rate Hedge in Japan, Inzinerine Ekonomika-Engineerig Economics, 2010, 21(2), 160-170.

[9] Mahmood Yahyazadehfar and Ahmad Babaie, Macroeconomic Variables and Stock Price, Middle-East Journal of Scientfic Research 11 (4): 408-415, 2012

[10] Mu-Lan, Ching-Ping and Tzu-Ying (2010), Relationship among Oil Price, Gold Price, Exchange Rate and International Stock Markets, International Research Journal of Finance and Economics, Issue 47 (2010)

[11] P K Mishra, J R Das and S K Mishra, Gold Price Volatility and Stock Market Returns in India, American Journal of Scientific Research, Issue 9(2010), pp.47-55

[12] Perry Sadorsky, Oil price shock and stock market activity, Energy Economics 21 (1999) 449-469

[13] Ramazan Safi and Ugur Soytas, The Relationship between Stock Returns, Crude Oil Prices, Interest Rates, and Output: Evidence from a Developing Ecomomy, The Emperical Economics Letters, 5(4): July(2006)

[14] Subarna K. Samanta and Ali H. M. Zadeh (2011), Co-Movement of Oil, Gold, the US Dollar, and Stocks, Modern Economy, 2012,3, 111-117 